UDC 338.22:004

DOI: https://doi.org/10.32782/2520-2200/2020-5-16

\author{
Dubnytskyi Volodymyr, Pysarkova Valeriia, \\ Naumenko Nataliia, Ovcharenko Olha \\ Ukrainian State University of Chemical Technology
}

\begin{abstract}
Дубницький B.I.
доктор економічних наук,

профресор кафедри підприємництва, організації виробництва

та теоретичної і прикладної економіки

ДВНЗ «Український державний хіміко-технологічний університет»
\end{abstract}

Науменко Н.Ю.

кандидат технічних наук,

доцент кафедри підприємництва, організації виробництва

та теоретичної і прикладної економіки

ДВНЗ «Український державний хіміко-технологічний університет»

Овчаренко О.В.

кандидат економічних наук, доцент кафедри підприємництва, організації виробництва та теоретичної і прикладної економіки ДВНЗ «Український державний хіміко-технологічний університет»

Писарькова В.P. аспірант, асистент кафедри підприємництва, організації виробництва та теоретичної і прикладної економіки ДВНЗ «Український державний хіміко-технологічний університет»

\title{
METHODICAL ASPECTS OF DIGITAL ECONOMY FORMATION: PROBLEMS AND PROSPECTS FOR UKRAINE
}

\section{МЕТОДИЧНІ АСПЕКТИ СТАНОВЛЕННЯ ЦИФРОВОЇ ЕКОНОМІКИ: ПРОБЛЕМИ ТА ПЕРСПЕКТИВИ ДЛЯ УКРАЇНИ}

The study found that in general, the concept of "digital economy" - an economy that can provide high-quality ICT infrastructure and mobilize the possibility of ICT for the benefit of consumers, businesses and the state. The article proposes the concept of "digital economy». The model of 8 factors of change of elements of external environment in the conditions of digital economy is presented. The digital economy adapts, changes and creates new, practically, in all elements of the external environment. The relationship between the digital economy and the external and internal environment is considered. Given the need to develop new methods of environmental analysis, the article presents data from a comparative analysis of the contribution of the digital economy to GDP in some countries and Ukraine in the following indicators: household expenditures in the digital sphere; companies' investments in digitalization; government spending on digitization; ICT exports; ICT imports; the size of the digital economy. Concept-levels of interaction of the national digital economy are offered. The author's algorithm of the modified approach to the account of influence of digital economy on cost of business of the economic entity which includes the following stages is presented: research of external and internal environment of the company; construction of the scenario of activity of the enterprise (company) planning tree; empirical substantiation of the materiality of the selected parameters; adjustment of the scenario of activity of the enterprise (company); substantiation of the value criterion, which takes into account the manifestation of the digital economy and the parameters of value; assessment of the impact of cost factors on the criteria; re-systematization and ranking of key cost factors; the ratio of digital and non-digital assets of the enterprise (company). The concept model of directions of development of digital economy of Ukraine for the period till 2030 which includes: digital transformation of branches 
of economy and cross-branch transformation is offered; digital transformation of markets for goods, services, capital and labor; digital transformation of integration processes management processes and development of digital infrastructure and ensuring security of digital processes.

Key words: digital economy, digital transformation, development, digital infrastructure, concept model, modified approach.

В статті запропоновано поняття «цифрова економіка». Представлена модель 8-ми факторів зміни елементів зовнішнього середовища в умовах цифрової економіки. Розглянуто взаємозв'язок цифрової економіки із зовнішнім та внутрішнім середовищем. Представлено авторський алгоритм модифрікованого підходу до обліку впливу цифрової економіки на вартість бізнесу господарюючого суб'єкту, який включає наступні етапи: дослідження зовнішнього та внутрішнього середовища компанії; побудову сценарію діяльності підприємства (компанії) - дерева планування; емпіричне обгрунтування суттєвості обраних параметрів; корегування сценарію діяльності підприємства (компанії); обгрунтування критерію вартості, який враховує прояв цифрової економіки та параметрів вартості; оцінку впливу фракторів вартості на критерійні значення; повторну систематизацію та ранжування ключових фракторів вартості; співвідношення цифрових та нецифрових активів підприємства (компанії). Запропоновано концепт-модель напрямів розвитку цифрової економіки України на період до 2030 року, яка включає в себе: цифрову трансформацію галузей економіки та крос-галузеву трансформацію; цифрову трансформацію ринків товарів, послуг, капіталу та робочої сили; цифрову трансформацію процесів управління інтеграційними процесами та розвиток цифрової інфрраструктури та забезпечення захищеності цифрових процесів.

Ключові слова: цифрова економіка, цифррова трансформація, розвиток, цифрова інфраструктура, концепт модель, модифрікований підхід.

В статье предложено понятие «цифровая экономика». Представлена модель 8-ми факторов изменения элементов внешней среды в условиях цифровой экономики. Рассмотрена взаимосвязь цифрровой экономики с внешней и внутренней средой. Представлен авторский алгоритм модифицированного подхода к учету влияния цифровой экономики на стоимость бизнеса хозяйствующего субъекта, который включает следующие этапы: исследование внешней и внутренней среды компании; построение сценария деятельности предприятия (компании) - дерева планирования; эмпирическое обоснование существенности выбранных параметров; корректировку сценария деятельности предприятия (компании); обоснование критерия стоимости, учитывающий проявление цифровой экономики и параметров стоимости; оценку влияния факторов стоимости на критериальные значения; повторную систематизацию и ранжирование ключевых фракторов стоимости; соотношение цифровых и нецифровых активов предприятия (компании). Предложено концепт-модель направлений развития цифровой экономики Украины на период до 2030 года, которая включает в себя: цифровую трансформацию отраслей экономики и кросс-отраслевую трансформацию; цифрровую трансформацию рынков товаров, услуг, капитала и рабочей силы; цифровую трансформацию процессов управления интеграционными процессами и развитие цифровой инфраструктуры и обеспечения защищенности цифровых процессов.

Ключевые слова: цифровая экономика, цифровая трансформация, развитие, цифровая инфраструктура, концепт модель, модифицированный подход.

Formulation of the problem. The concepts of "digital economy", "knowledge economy", «information society" form a new socio-economic system that replaces the industrial paradigm. In the new economic environment, all economic entities that strive for sustainable operation are forced to go through a process of digital transformation. Digital transformation, in the interpretation of the authors, is the introduction of modern technologies in the business processes of socio-economic systems at all levels. The digital economy sets the vector by which socio-economic systems of micro-, meso-, macro-levels will develop in the long run, which necessitates research and comprehensive analysis of digital transformation processes. The business community and the authorities of the world, including Ukraine, are aware of the need, in the economic and financial crisis and the impact on the economy of the coronavirus pandemic, to accelerate digitalization processes in order to achieve competitive positions in the emerging digital space of the world economy which requires analytical and scientific-methodical elaboration of the implementation of such changes.

Analysis of scientific publications. The degree of scientific elaboration of these problems is determined by the novelty of its occurrence and the associated still weak elaboration of the processes of digital transformation in the industry of Ukraine. The concept of the digital economy and the mechanisms of transition to it of the industrial complex, in particular large corporations, are considered in the works of foreign and domestic authors such as 
Klaus Schwab, D. Tapskatt, B. Hiller, K. Kukver, E. Weissman, K. Wertheim and J. Fenvik, K. Anderson, N. Klaus, O. Trofimov, A. Sahakyan, N. Kurmanov, V. Rogov, O. Rozgon, A. Kunuman, E. Istomina, I. Avdeeva, A. Polyanin, O. Shchedrykova, as well as M. Oulander, V. Lyashenko, O. Hudz, V. Zanor, G. Tkachuk, S. Shcheglyuk, O. Shafalyuk, S. Ilyashenko, V. Ruban and others.

The purpose of the work. Develop methodological aspects of the formation of the digital economy in Ukraine in terms of problems and prospects.

Presentation of the main material of the study. The modern world economic system is in a situation where a significant share of GDP in developed countries is the activity of generating, processing, storing and disseminating information. As noted in the study of A. Kukuman, business information refers to the key resources of enterprises in almost all industries [1, p. 14]. Increasing the role of information and business knowledge, the need to reduce production costs and the rapid development of digital information technology has contributed to the emergence of a virtually new type of economy - the digital economy.

Current trends in the economic development of most countries of the world economic society consider digital transformation as the main priority. For an adequate idea of the scale of the process, it is necessary to assume that digitalization is understood not as a separate area and set of technologies, but as an algorithm for the development of relations in modern society and its cultural environment. Today, digitization can be included in dictionaries as a homonym, as it carries different meanings. But the main thing is that the concept has already been on the agenda of meetings of the board of large industrial enterprises.

Under the digital economy we understand the modern type of economy, which is characterized by the predominant role of information and knowledge as determining resources in the production of material products and services, as well as the active use of digital technologies for collecting, storing, processing and transmitting information.

The term «digitization» in the elementary sense refers to a system of measures necessary to make production more flexible, with the potential to adapt to innovation in conditions of "fierce" competition, that is adapted to the realities of the modern world (financial crises and planetary parondemics and other) and competitive in the nascent "digital» world. Digitization is a means of obtaining the desired result, namely flexible production, which brings customers a great result, and owners - higher profits. Digital transformation is the process of transforming enterprises from the current state to flexible.
The subject of digital economy in the most general form are economic relations that develop in the process of production, exchange, distribution and consumption of scientific and technical information using digital technologies and information and communication technologies, as well as economic laws governing the development of these processes. The development of the digital economy is inextricably linked with the formation of the so-called «information society". The origin of this term is associated with the American economist F. Makhlup, who studied in his work «Production and distribution of knowledge in the United States" information cluster of the American economy in the 1960s. Later, this concept was used in the works of Japanese, American and European scientists. According to the work of S.A Dyatlov, society at the current stage of its development is entering the most mature phase of scientific and technological progress - information. This phase can be described as information-network [2].

In fact, the digital economy is a holistic, systematic, comprehensive program for finding the model of human relations that is compatible with digital technologies of the XXI century, including within the fourth industrial revolution, in its formation of development and implementation must ensure the achievement of objectively. Thanks to digital, network and intelligent technologies, modern economic activity becomes more flexible, dynamic, manageable. Most developed countries, such as the United States, Japan, Germany, France, Canada, China, Singapore, consider the formation of conditions for the development of the digital economy as a strategic goal.

Thus, as noted in the work of E.V Popov and K.A Semyachkov [3], the emphasis on the priority areas of digital development of the modern economy, which contribute to economic growth, increasing the stability of budgets, strengthening social cohesion, as well as the importance of the digital economy, which should play a role in ensuring sustainable development of socio-economic systems. structural reforms and progressive transformations around the world. It should be noted that modern information networks are an effective infrastructure for data exchange, and the effective use of information and communication technologies is an important driving force for increasing the efficiency and effectiveness of the national economy, as well as optimizing its structure.

In Figure 1 presents a model of 8 factors of environmental change in a digital economy.

We should agree with the point of view of researchers $[4 ; 5 ; 6 ; 7 ; 8]$, which, of course, the development of digital technologies and information and communication technologies leads to 


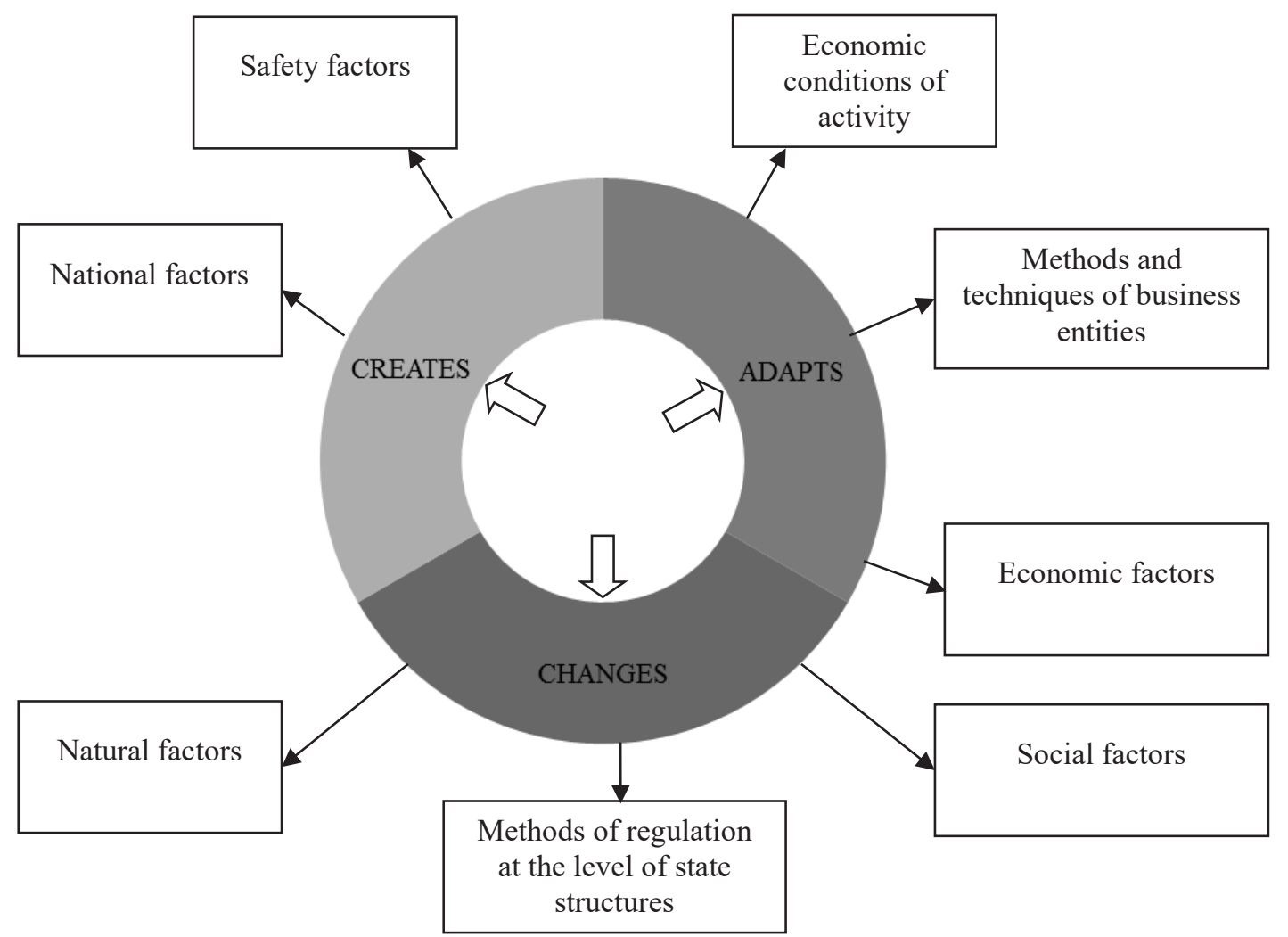

Figure 1. Model of 8 factors of change of elements of external environment

the formation of a new segment of the economy (including the design of new markets with their actors - digital companies), but already now, not only in the USA, Japan, Germany, China, it is possible to talk about fully digital companies of other countries, including Ukraine (business models that are implemented in the digital environment), and about companies that implement digital technologies for improving their activities (the introduction of digital technologies in basic business processes).

The digital economy is recognized by most well-known scientists and top managers of the largest corporations as a current megatrend of modern society, business, public administration, life. The formation of the global digital space is another stage in the chain of «new industrialization - digitalization" and caused by the need to provide technological and information-psychological leadership of businesses and transnational corporations and states in general on the basis of information and communication and related technologies. These processes are accompanied by the modernization of traditional industries and services and the reformatting of trade and procurement and logistics and marketing activities.

Adapting the study of the digital economy as a modern environment should pay attention to the fact that this phenomenon can't be attributed only to a new factor, albeit such a global one. The digital economy adapts, changes and creates new, practically, in all elements of the external environment. In Figure 2 shows the relationship of the digital economy with the external and internal environment.

First of all, the economic conditions of activity are changing (starting from the methods and means of payment to the organization of logistics flows), the ways and methods of the economic entities are changing (from transferring activities to digital space to using fundamentally new technologies, including artificial intelligence), changing economic factors in terms of creating new (digital) barriers and the formation of oligopolistic "collusion" of digital market leaders), changing social factors (most clearly manifested in the widespread use of social networks and messengers), changing national factors (so developing countries will have a chance to become developed countries, no longer burdened by the technological gap), natural factors are changing (again there is a need to study environmental and other factors that reflect the energy consumption of cryptocurrencies), changing methods of regulation at the state and international structures, new economic and information factors information security.

Given the above, it should be noted that it is necessary to develop new methods of environmental analysis. Table 1 presents data from a comparative analysis of the contribution of the digital economy to the GDP of some countries and Ukraine. 
To adapt the methodology of environmental analysis within $\mathrm{DE}$, according to the author of the study Sh.R. Huseynov should identify and classify the manifestations of "figures" at different levels of management, first of all it is necessary to determine the system-forming factors in the formation of the digital economy:

- formation of a qualitatively new structure of economic assets that meet the economic priorities of $\mathrm{DE}$;

- use of electronic technologies and services;

- formation and support of favorable organizational, informational, infrastructural and normative-legal characteristics of development of DT and ICT;

- collection and processing of large data sets in digital form (Big Data);

- development of digital economy institutions;

- preserving the sovereignty of countries in the context of economic globalization;

- ensuring economic and information security of the state, business, society and people;

- promoting the quality of life of citizens;

- protection of personal data and privacy of citizens in the digital space [9, p. 57-58].

In our opinion, such a variety of factors, despite the direct relationship with information technology, has influenced the identification of DE in various documents and individual studies of specialists and experts $[2 ; 3 ; 4 ; 8 ; 10]$. When referring to foreign researchers $[5 ; 6 ; 7]$ of with have certainly already accumulated considerable experience in identifying the factors of DE and digital transformation of the economy, from our point of view there is a need to first refer to the results of understanding

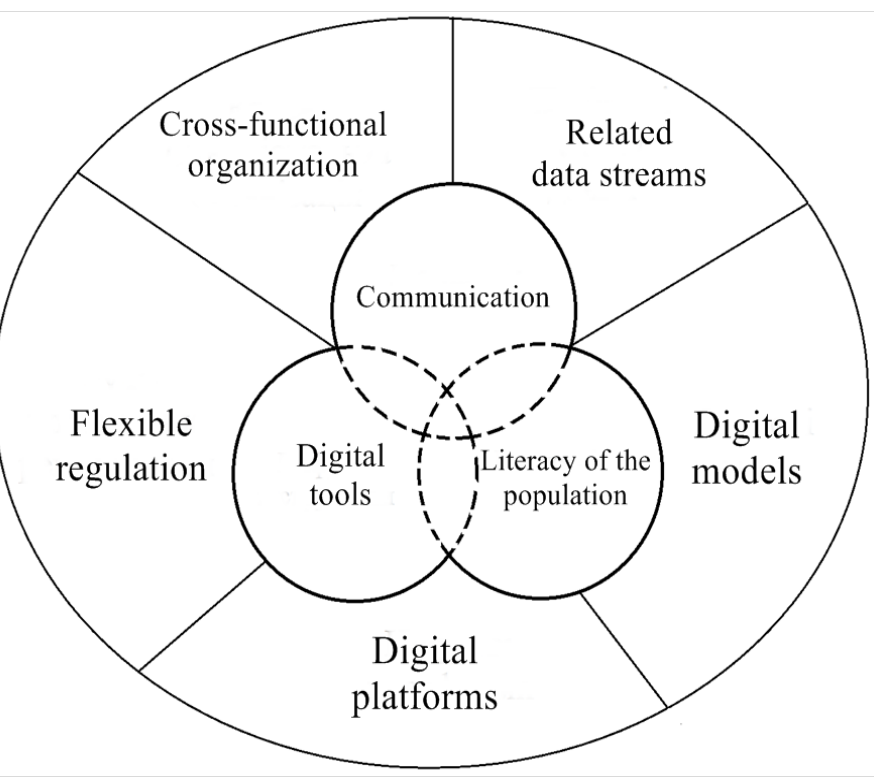

Figure 2. The relationship of the digital economy with the external and internal environment

the current trend in the economy, which is referred to as «new industrialization», or as a «new industrial revolution" (in the context of the concept of «industry $4.0 \%)$ and which is inextricably linked with the manifestations of the digital revolution.

From the point of view of a number of foreign scientists, the new industrialization doesn't consider modernization solely from the standpoint of information technology dissemination - in this sense is concentrated the mechanism of radical technological modernization of production within $\mathrm{V}$ and $\mathrm{VI}$ technological modes, (in traditional industries). technologies (nano-bio-information and cognitive technologies) [10; 11; 12]. Also of interest is the forecast of the spread of digital infrastructure in the world until 2060, made by experts of the World Economic Forum (Figure 3).

Comparative analysis of the contribution of the digital economy to the GDP

Table 1 of some countries and Ukraine (\% of GDP)

\begin{tabular}{|c|c|c|c|c|c|c|c|c|c|c|}
\hline \multirow[b]{2}{*}{ Indicator } & \multirow{2}{*}{ 芯 } & \multirow{2}{*}{ 胥 } & \multirow{2}{*}{ 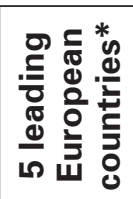 } & \multirow{2}{*}{$\stackrel{\frac{\pi}{\bar{g}}}{\underline{\underline{a}}}$} & \multirow{2}{*}{ 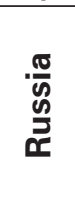 } & \multirow{2}{*}{$\begin{array}{l}\overline{\bar{N}} \\
\bar{\Xi} \\
\bar{\Phi}\end{array}$} & \multirow{2}{*}{$\begin{array}{l}\text { ¿ } \\
\mathbb{J} \\
\text { U }\end{array}$} & \multirow{2}{*}{ 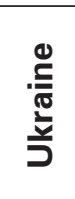 } & \multicolumn{2}{|c|}{$\begin{array}{c}\text { Ukraine lags } \\
\text { behind }\end{array}$} \\
\hline & & & & & & & & & ङ & 胥 \\
\hline $\begin{array}{l}\text { Household expenditures } \\
\text { in the digital sphere }\end{array}$ & 5,3 & 4,8 & 3,7 & 3,2 & 2,6 & 2,6 & 2,2 & 0,9 & 4,4 & 3,9 \\
\hline $\begin{array}{l}\text { Investments of companies } \\
\text { in digitalization }\end{array}$ & 5,1 & 1,8 & 3,9 & 2,7 & 2,2 & 3,6 & 2,1 & 1,1 & 4,0 & 0,7 \\
\hline $\begin{array}{l}\text { Government spending } \\
\text { on digitization }\end{array}$ & 1,3 & 0,6 & 1,1 & 0,6 & 0,4 & 0,8 & 0,5 & 0,3 & 1,0 & 0,3 \\
\hline ICT exports & 1,4 & 5,8 & 2,5 & 5,9 & 0,5 & 0,1 & 2,9 & 0,2 & 1,2 & 5,6 \\
\hline ICT imports & $-2,1$ & $-2,7$ & $-2,9$ & $-6,1$ & $-1,8$ & $-1,1$ & $-2,1$ & $-7,3$ & $-5,2$ & $-3,5$ \\
\hline $\begin{array}{l}\text { The size of the digital } \\
\text { economy }\end{array}$ & 10,9 & 10,0 & 8,2 & 6,3 & 3,9 & 6,2 & 5,5 & 1,8 & 9,1 & 8,2 \\
\hline
\end{tabular}

* Great Britain, Germany, Italy, France, Sweden 


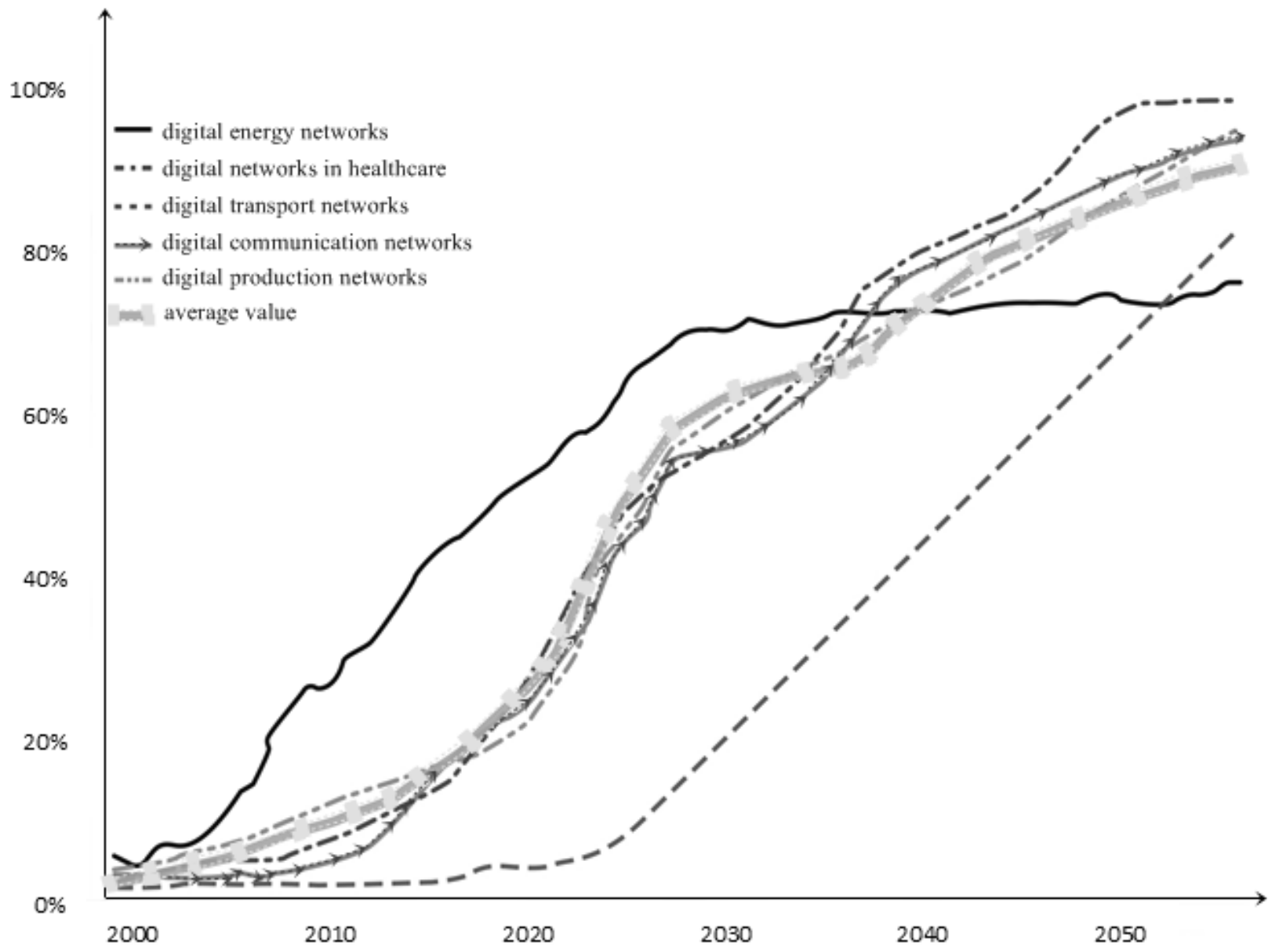

Figure 3. Distribution of digital infrastructure in the world by years

Figure 4 presents the author's algorithm of a modified approach to accounting for the impact of $D E$ on the business value of the business entity (enterprises, companies, corporations, innovation cluster structure).

The digital economy stimulated the emergence and development of a phenomenon called «attention economy». The digital network economy promotes long-term partnerships, which reduces the transparency of transactions [13].

The effectiveness of the network economy directly depends on the critical mass of entities capable of network integration. In general, the economy, built on network principles, includes the following components: economic business entities and their network connections, digital products, turnover, pricing, digital infrastructure. According to the authors, it is important to identify the impact of DE on business and the formation of a new economy is to develop a modified approach to accounting for the impact of $D E$ on the value of business (this is especially important for corporate business structures).

In Ukraine and its regions, digital restructuring is taking place at a satisfactory level. Virtually all sectors of the domestic economy have begun to carry out the process of digital transformation in order to keep pace with progress and increase their efficiency. There is an understanding in the domestic business environment that the digitalization of the economy and its comprehensive security won't only increase the country's competitiveness and the potential of enterprises to enter world markets, but will also help ensure economic growth and national sovereignty. Figure 5 presents the concept of levels of interaction of the national digital economy.

The authors developed a concept model of DE directions of Ukraine for the period up to 2030 (Table 2).

For the conditions of Ukraine within the implementation of the digital transformation of the domestic economy, the priority areas in the implementation of the DE program are:

- first, the creation of information products and services;

- secondly, building a new business model;

- thirdly, the development of social relations in this environment and human capital based on the opportunities that the digital economy opens up.

The key vectors in the implementation of the national program "digital economy" include six 


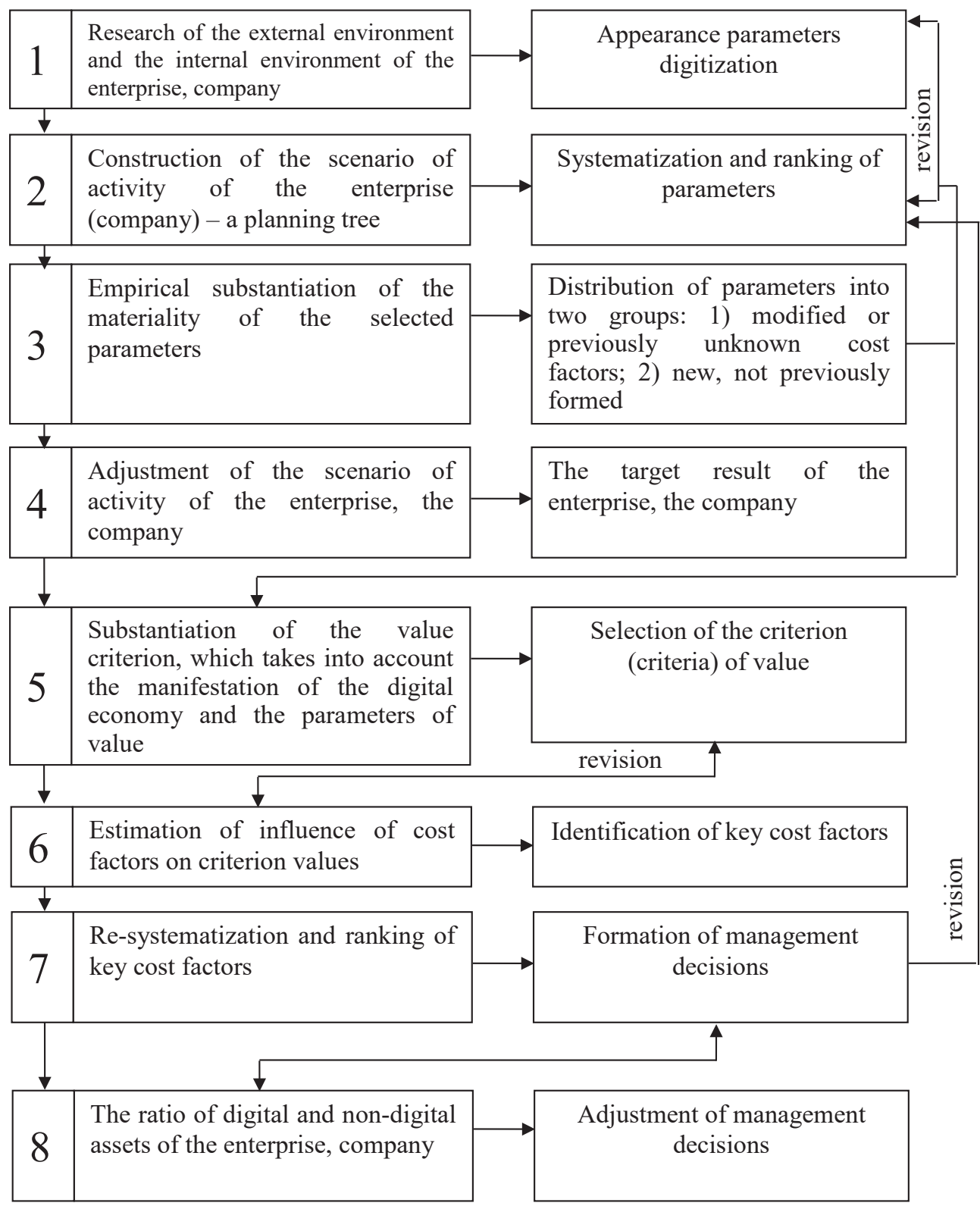

Figure 4. Algorithm of the modified approach to the account of influence of digital economy on business cost

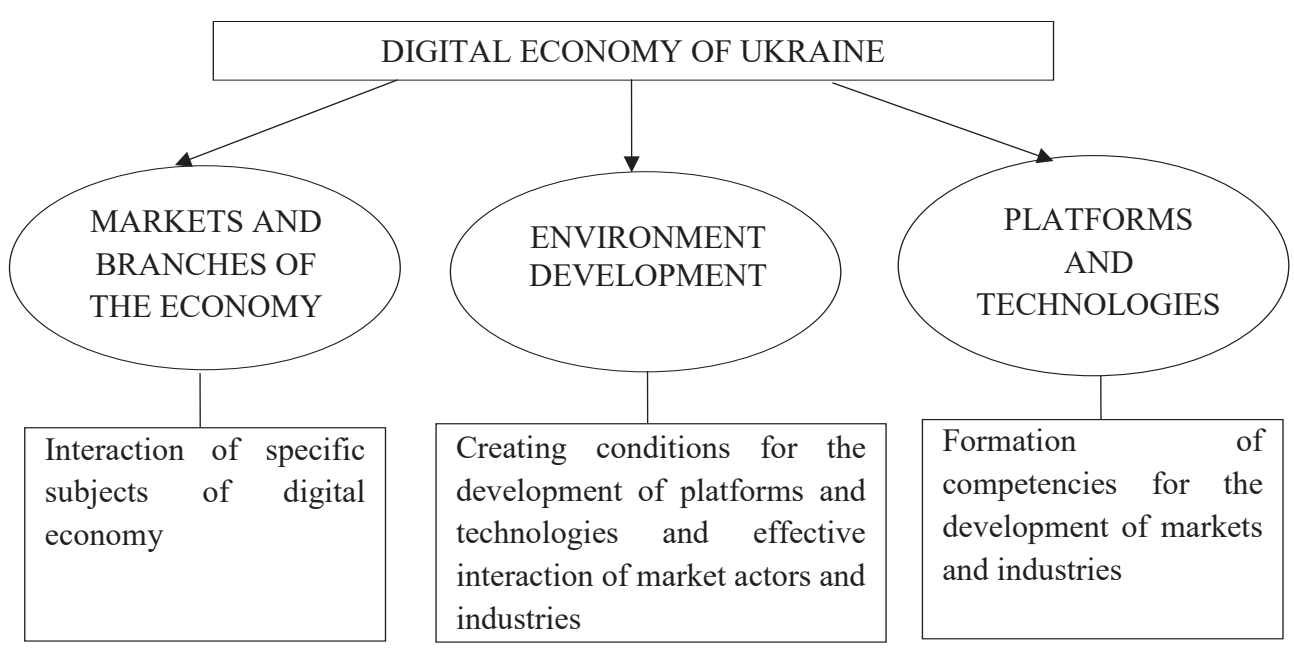

Figure 5. The concept of levels of interaction of the national digital economy 


\section{Concept model of directions of development of digital economy of Ukraine (for the period till 2030)}

Concept model of directions of development of digital economy of Ukraine (for the period till 2030)

\begin{tabular}{|c|c|}
\hline 1 & 2 \\
\hline $\begin{array}{l}\text { Digital transformation } \\
\text { of industries and cross- } \\
\text { industry transformation }\end{array}$ & $\begin{array}{l}\text { - vertical integration of processes within the industry and within industry } \\
\text { enterprises } \\
\text { - interaction of different branches of the economy of Ukraine, creation of } \\
\text { new business models and end-to-end digital processes through traditional } \\
\text { junctions of branches (intersectoral cooperation) } \\
\text { - horizontal integration of processes and construction of cross-sectoral, } \\
\text { interstate and transnational processes } \\
\text { - end-to-end digitization of products, services, business models and their } \\
\text { integration into the digital ecosystem on the basis of a digital platform or } \\
\text { complexes of digital platforms } \\
\text { - formation of digital platforms as a type of digital assets that operate in } \\
\text { various traditional and new industries (to ensure cooperation of economic } \\
\text { entities), around some digital images (objects) } \\
\text { - participation in value chains based on the analysis of useful data, the use } \\
\text { of digital models and end-to-end processes } \\
\text { - priority areas of integration cooperation (industry, agriculture, transport, } \\
\text { energy, pharmaceuticals, etc.) }\end{array}$ \\
\hline $\begin{array}{l}\text { Digital transformation } \\
\text { of markets for goods, } \\
\text { services, capital and } \\
\text { labor }\end{array}$ & $\begin{array}{l}\text { - use of Internet technologies to reduce costs, reduce the number of } \\
\text { intermediaries, reduce barriers to market entry } \\
\text { - development of the digital market to ensure the free movement of goods, } \\
\text { services, capital and labor } \\
\text { - development of professional digital skills and creative potential for gradual } \\
\text { increase of labor productivity } \\
\text { - ensuring the mobility of labor resources, the development of remote } \\
\text { employment and employment; } \\
\text { - stimulating business in digital form } \\
\text { - coordination of actions in the field of protection of intellectual property } \\
\text { rights and consumer rights of the digital market } \\
\text { - promotion of financial and technological innovations, development of } \\
\text { compatible mechanisms of risky, alternative and venture financing of digital } \\
\text { innovations }\end{array}$ \\
\hline $\begin{array}{l}\text { Digital transformation } \\
\text { of integration } \\
\text { processes } \\
\text { management } \\
\text { processes }\end{array}$ & $\begin{array}{l}\text { - development of digital models, procedures, tools, procedures, standards } \\
\text { and methodology of project management within the digital economy of } \\
\text { Ukraine and its regions } \\
\text { - development of interstate electronic services } \\
\text { - ensuring interoperability and digital transformations at the state and } \\
\text { supranational level } \\
\text { - ensuring the synchronization of ongoing projects (taking into account the } \\
\text { mechanisms of tracking, labeling, industrial cooperation) } \\
\text { - development of EU digital platforms for interstate information interaction, } \\
\text { development of digital ecosystems, formation of a system of unified } \\
\text { regulatory and reference information }\end{array}$ \\
\hline $\begin{array}{l}\text { Development of digital } \\
\text { infrastructure and } \\
\text { ensuring the security } \\
\text { of digital processes }\end{array}$ & $\begin{array}{l}\text { - implementation of framework projects for the development of digital } \\
\text { infrastructure } \\
\text { - cooperation to ensure the sustainability, continuity and reliability of } \\
\text { infrastructures for the development of initiatives and project implementation } \\
\text { - organization of information exchange with the use of interstate electronic } \\
\text { document management } \\
\text { - development of tools for protection of digital processes and adaptation of } \\
\text { digital format in information security systems } \\
\text { - development of standards and methodologies for the formation of digital } \\
\text { infrastructure at the regional level, as well as ensuring its information } \\
\text { security }\end{array}$ \\
\hline
\end{tabular}


basic areas: regulatory regulation of the digital environment; total informatization; informational security; digital and IR technologies; digital literacy and competence of personnel in the field of DE; digital public administration. At the same time, it is obvious that in order to ensure the stability of Ukraine's economy due to digital transformation and digitalization, a balanced development of all its constituent elements is necessary. However, of course, to ensure the sustainability of national $D E$, special attention should be paid to the formation of an appropriate regulatory environment that will promote the development of a favorable legal regime for the emergence and implementation of modern ICT, as well as economic activities related to their use in DE $[8 ; 14 ; 15 ; 16]$.

Conclusions. The study found that in general, the concept of "digital economy" - an economy that can provide high-quality ICT infrastructure and mobilize the possibility of ICT for the benefit of consumers, businesses and the state. It can also be stated that the digital transformation of the economy captures mainly economic and consists in the emergence of new activities, as well as the digitization of traditional industries. At the same time, a number of scientists associate this (next) "wave" of the introduction of ICT with the formation of a new technological way of life - Industry 4.0. It should be understood that Industry 4.0 is based on the production of equipment that uses ICT and DT and related software. It is important to note that the peculiarity of the modern digital transformation of the economy is that the new ICT and CT allow to automate not only physical actions, but also some intellectual functions.

If you don't reduce it to e-commerce and services, it can be considered as a new stage of automation, which allows you to solve complex problems. Also important is the fact that at the same time digitalization processes require the implementation of a number of cross-cutting projects: information resources, digital platforms and conditions for their operation. Experts state that the level of digital trust is a key condition for the development of the global and national digital economy. At the same time, the main problem of digital transformation is the need for mass education and retraining of people, on a scale comparable to the changes of the era of industrialization.

And most importantly, insufficient level of modern scientific knowledge, in fact the difficult state of Ukraine's economy, lack of necessary financial resources, as well as practical unpreparedness for digital management marketing hinders the development of optimal solutions (strategies and programs) that would offset the negative effects and contribute domestic industry) manifestation of the full positive effects of the digitalization process.

\section{References:}

1. Kuicman A.A. (2017) Specifika adaptacii sovremennyh kompanij k usloviyam cifrovoj ekonomiki [The specifics of adaptation of modern companies to the digital economy]. Innovacii - Innovation, pp. 14-21. (in Russian)

2. Dyatlov S.A. (2008) Informacionno-setevaya ekonomika: struktura, dinamika, regulirovanie [Information network economy: structure, dynamics, regulation]. SPb: Asterion, pp. 50-66. (in Russian)

3. Popov E.V. \& Semyachkov K.A. (2018) Komparativnyj analiz strategicheskih aspektov razvitiya cifrovoj ekonomiki [Comparative analysis of strategic aspects of the development of the digital economy]. Vestnik Perm' - Bulletin Perm, 13(1), pp. 19-36. (in Russian)

4. Shepenkivs'kij V.G. (2011) Informacijna bezpeka yak skladova suchasnogo obrazu Ukraini [Information security as a component of the modern image of Ukraine]. Aktual'ni problemi mizhnarodnih vidnosin - Current issues of international relations, 102(1), pp. 219-228. (in Ukrainian)

5. Chzhan D. (2017) Sovremennoe sostoyanie cifrovoj ekonomiki Kitaya i perspektivy sotrudnichestva mezhdu Kitaem i Rossiej $v$ dannoj oblasti [The current state of China's digital economy and the prospects for cooperation between China and Russia in this area]. Vlast' - Power, 9, pp. 37-43. (in Russian)

6. Hiller B. (2017) Industriya 4.0 - umnoe proizvodstvo budushchego. Opyt cifrovizacii Germanii [Industry 4.0 - smart manufacturing of the future. Experience of digitalization in Germany]. Mezhd. forum "Informacionnoe modelirovanie dlya infrastrukturnyh proektov i razvitiya biznesa bol'shoj Evrazii» - International Forum "Information Modeling for Infrastructure Projects and Business Development in Greater Eurasia». http://3d-conf.ru. Retrieved from: http://3d-conf.ru/pdf-2017/ hiller.pdf (in Russian)

7. Nye J.S. \& Owens W.Jr. America's Informational edgel strategy and planning. (n.d.). https://ics.leeds.ac.uk. Retrieved from: https://ics.leeds.ac.uk/paper/Vp01.cfm?outfit=pmt\&requesttimeout $=500 \&$ folder $=498$ paper $=155$

8. Lyashenko V.I. \& Vishnevs'kij O.S. (2018) Cifrova modernizaciya ekonomiki Ukraini yak mozhlivist' prorivnogo rozvitku [Digital modernization of Ukraine's economy as an opportunity for breakthrough development]: monografiya - a monograph. Kyiv: IEP NAN Ukraini, 252. Retrieved from: http://iep.com.ua/7/Lyashenko_Vishevsky_2018.pdf (in Ukrainian) 
9. Gusejnov Sh.R. (2019) Metodologiya upravleniya stoimost'yu korporativnyh obrazovanij v usloviyah cifrovoj ekonomiki [Methodology for managing the value of corporate entities in the digital economy]. Extended abstract of Doctor's thesis. Moscow: MGIMO(U). (in Russian)

10. Gilyaeva G.A. (2019) Cifrovaya zrelost' predpriyatiya: metody ocenki i upravleniya [Digital maturity of an enterprise: methods of assessment and management]. Vestnik UGNTU - nauka, obrazovanie, ekonomika. Seriya "ekonomika» - Bulletin of UGNTU - science, education, economics. Series "economics», 1(27), pp. 38-52. (in Russian)

11. Brynjolfsson E. \& Kahin B. (2002) Understanding the Digital Economy: Data, Tools and Research. MIT Press, $401 \mathrm{p}$.

12. Sehwab K. (2017) The Fourth Industrial Revolution. Crown Business. New York, 192 p.

13. Kulinicheva N.A. (2019) Analiz skvoznyh tekhnologij, vliyayushchih na cifrovuyu ekonomiku [Analysis of end-to-end technologies affecting the digital economy]. Veb. nauch. tr. "Vyzovy cifrovoj ekonomiki: itogi i novye trendy" - webinar of scientific papers "Challenges of the digital economy: results and new trends». Bryansk: BGITU, pp. 276-280. (in Russian)

14. Oklander M.A., Oklander T.O. \& YAshkina O.I. (2017) Cifrovij marketing - model' marketingu XXI storichchya [Digital marketing - a marketing model of the XXI century]: Monografiya - A monograph. Odesa: Astroprint, 292 p. (in Ukrainian)

15. Kraus N.M., Goloborod'ko O.P. \& Kraus K.M. (2018) Cifrova ekonomika: trendi i perspektivi avangardnogo harakteru rozvitku [Digital economy: trends and prospects of avant-garde nature of development]. Efektivna ekonomika - Effective economy. (in Ukrainian)

16. Koncepciya rozvitku cifrovoi ekonomiki ta suspil'stva Ukraini na 2018-2020 roki "skhvaleno» rozporyadzhennyam KMU vid 17 sichnya 2017 № 67-r [The concept of development of the digital economy and society of Ukraine for 2018-2020 "approved" by the order of the Cabinet of Ministers of January 17, 2017 № 67-r]. (2014, January 17). (in Ukrainian)

\section{Список використаних джерел:}

1. Куицман А.А. Специфика адаптации современных компаний к условиям цифровой экономики. Инновации. 2017. № 9(227). С. 14-21.

2. Дятлов С.А. Информационно-сетевая экономика: структура, динамика, регулирование. Санкт-Петербург : Астерион, 2008. С. 50-66.

3. Попов Е.В., Семячков К.А. Компаративный анализ стратегических аспектов развития цифровой экономики. Вестник Пермь: ГУ. 2018. Т. 13.1. С. 19-36.

4. Щепенківський В.Г. Інформаційна безпека як складова сучасного образу України. Актуальні проблеми міжнародних відносин. 2011. Вип. 102 (ч. 1). С. 219-228.

5. Чжан Д. Современное состояние цифровой экономики Китая и перспективы сотрудничества между Китаем и Россией в данной области. Власть. 2017. № 9. С. 37-43.

6. Хиллер Б. Индустрия 4.0 - умное производство будущего. Опыт цифровизации Германии. Межд. форум "Информационное моделирование для инфбраструктурных проектов и развития бизнеса большой Евразии. 2017. URL: http://3d-conf.ru/pdf-2017/hiller.pdf (дата звернення: 03.09.2020).

7. Nye J.S., Owens W.Jr. America's Informational edgel strategy and planning. URL: https://ics.leeds.ac.uk/ paper/Vp01.cfm?outfit=pmt\&requesttimeout=500\&folder =498paper=155 (дата звернення: 10.09.2020).

8. Ляшенко В.І., Вишневський О.С. Цифрова модернізація економіки України як можливість проривного розвитку : монографрія. Київ : IEП НАН України, 2018. 252 c. URL: http://iep.com.ua/7/ Lyashenko_Vishevsky_2018.pdf (дата звернення: 20.08.2020).

9. Гусейнов Ш.Р. Методология управления стоимостью корпоративных образований в условиях цифровой экономики : дис. ... д.э.н. : 08.00.05. Москва, 2019. 320 с.

10. Гиляева Г.А. Цифровая зрелость предприятия: методы оценки и управления. Вестник УГНТУ наука, образование, экономика. Серия «экономика». 2019. № 1(27). С. 38-52.

11. Brynjolfsson E., Kahin B. Understanding the Digital Economy: Data, Tools and Research. MIT Press. 2002. $401 \mathrm{p}$.

12. Sehwab K. The Fourth Industrial Revolution. Crown Business. New York, 2017. 192 p.

13. Кулиничева Н.А. Анализ сквозных технологий, влияющих на цифровую экономику. Веб. науч.тр. «Вызовы цифровой экономики: итоги и новые тренды». Брянск : БГИТУ, 2019. 696 с.

14. Окландер М.А., Окландер Т.О., Яшкіна О.І. Цифровий маркетинг - модель маркетингу XXI сторіччя : монографрія / за ред. М.А. Окландерра. Одеса : Астропринт, 2017. 292 с.

15. Краус Н.М., Голобородько О.П., Краус К.М. Цифрова економіка: тренди і перспективи авангардного характеру розвитку. Ефбективна економіка. 2018.

16. Концепція розвитку цифрової економіки та суспільства України на 2018-2020 роки / «схвалено» розпорядженням КМУ від 17 січня 2017 № 67-р. 